\title{
Occurrence of Cylindrospermopsis (Cyanobacteria) in 39 Brazilian tropical reservoirs during the 1998 drought
}

\author{
Marc Bouvy ${ }^{1, *}$, Diogo Falcão ${ }^{2}$, Mauro Marinho², Marc Pagano ${ }^{3}$, Ariadne Moura ${ }^{4}$ \\ ${ }^{1}$ Institut de Recherche pour le Développement (IRD), 911 Avenue Agropolis, 34032 Montpellier cedex 1, France \\ ${ }^{2}$ Secretaria dos Recursos Hídricos (SRH), 180 Casa Forte, Recife/PE, 52061-070, Brazil \\ ${ }^{3}$ IRD, Centre Océanologique, rue de la Batterie des Lions, 13007 Marseille, France \\ ${ }^{4}$ Universidade Federal Rural de Pernambuco (UFRPE) , Recife/PE, 52175-030, Brazil
}

\begin{abstract}
The relationship between the trophic state of 39 reservoirs located in the semi-arid region of north-east Brazil and their planktonic structure was examined by a sampling survey during the 1998 drought (September to November). A total of 30 environmental and biological parameters, with special attention paid to phytoplankton, were studied once at each reservoir to obtain a synoptic view at a state scale (Pernambuco State). The application of the chlorophyll a-total phosphorus standard relationship for grades of eutrophication revealed a classification in which $90 \%$ of the sites were eutrophic-hypertrophic. Among the 202 taxa identified in the phytoplankton assemblages, the cyanobacterium Cylindrospermopsis (Wolsz.) Seenayya et Subba Raju represented more than $80 \%$ of the total phytoplankton density in 10 reservoirs and more than $50 \%$ in 17 reservoirs. The rarity of other phytoplanktonic groups in the case of the Cylindrospermopsis dominance is the most significant biological feature of these reservoirs. Although rotifers were more closely linked to hypereutrophic conditions than copepods or cladocerans, this dominant group did not seem to play an efficient role in cyanobacterial control. A statistical approach based on the analysis of cross tables (co-inertia analysis) allows us to describe species-environment relationships with a special focus on the factors governing the presence of Cylindrospermopsis. As determined by hierarchical analysis, a major group of studied reservoirs $(70 \%)$ corresponded to deeper, warmer and hypertrophic reservoirs characterized by the combination of (1) low ammonia concentration, high temperature and $\mathrm{pH}$ values, and (2) high percentages of Cylindrospermopsis abundances. Lack of water renewal in 1998 linked to the 1997 El Niño consequences seems to be a major determinant for both trophic conditions and Cylindrospermopsis dominance in the reservoirs studied.
\end{abstract}

KEY WORDS: Bacteria · Phytoplankton · Zooplankton · Cylindrospermopsis · El Niño event · Reservoirs $\cdot$ Co-inertia analysis

Resale or republication not permitted without written consent of the publisher

\section{INTRODUCTION}

The north-eastern region of Brazil, referred to as the Drought Polygon, is subject to recurrent droughts. Policies have aimed at providing the means to store water for use during extended periods of drought. The reliance on surface reservoirs has been referred to as

\footnotetext{
*E-mail: bouvy@mpl.ird.fr
}

the 'Açudes' (Brazilian name for reservoir, generally man-made) policy. Although many of these reservoirs are used for water consumption, most are designed for multiple purposes such as irrigation, bathing, fishing and ranching. Unfortunately, the incidence of water blooms of toxic cyanobacteria is also frequent in these ecosystems. Recently, the use, for kidney dialysis, of a water supply contaminated with microcystins (Azevedo 1996, Jochimsen et al. 1998) resulted in human liver failure causing death in Brazil (Caruaru tragedy). 
Cyanobacteria are recognized as a critical problem worldwide and their blooms are typical phenomena in eutrophic lakes, often linked to external nutrient enrichment (Paerl 1988). The influence of local climatological factors (e.g. wind, light intensity, temperature) can accelerate these phenomena and modify the phytoplankton structure, as cyanobacteria are strongly driven by physical factors such as local weather conditions (e.g. Tóth \& Padisák 1986, Fabbro \& Duivenvoorden 1996, Bouvy et al. 1999). Other factors that potentially influence the biomass and composition of phytoplankton include a stable water column with a turbulence limitation defined as a high ratio between the mixing zone and the euphotic zone (Soranno 1997). In addition, cyanobacteria are inedible prey for many zooplankton organisms because of their large colony size, their toxic effects and low nutritional value (Boon et al. 1994).

Moreover, the disruption of food webs can be another environmental problem favoring the predominance of toxin-producing planktonic cyanobacteria (Carmichael 1994). In the case of blooms or scums, cyanobacteria pose a series of problems for water quality, fisheries resources, aquaculture, and human health (Codd 1995). A wide range of potent toxins can be produced by cyanobacteria, including cyclic peptide hepatotoxins and alkaloid neurotoxins such as the paralytic shellfish poisons (PSPs) (Carmichael 1994). Among the toxic cyanobacteria, the genus Cylindrospermopsis is well represented and some species (C. raciborskii) can represent major components of phytoplankton communities and form water blooms in tropical and temperate freshwater ecosystems (see review in Padisák 1997).

Although people in all parts of Brazil have long been aware of the quality and biotic resources of their lakes and rivers (e.g. Tundisi et al. 1993), very little information exists on the hydrobiological characteristics of the reservoirs in the north-east semi-arid region. Available quantitative and qualitative accounts of the plankton structure (bacteria, ciliates, phytoplankton) and phytoplankton assemblages in some reservoirs may be found in Bouvy et al. (1998a) and Huszar et al. (2000), respectively. Studies based on seasonal variations of different limnological parameters in 2 drinking water supplies (Ingazeira and Tapacurá) were conducted over a period of $2 \mathrm{yr}$ to enable a better understanding of the factors related to cyanobacterial blooms of Cylindrospermopsis raciborskii (Bouvy et al. 1999, Nascimento et al. 2000). A serious problem linked to this cyanobacterium is its patent toxicity which poses a potential risk for neighboring populations (Lagos et al. 1999). Another crucial problem is obvious doubt concerning the taxonomic position of some Cylindrospermopsis morphotypes (Komárková et al. 1999), and it is clear that genetic approaches will be necessary to clarify Cylindrospermopsis taxonomy and morphological properties (Saker et al. 1999). In 1998 a monitoring program, focused on the occurrence of the genus Cylindrospermopsis, was established, including a large-scale limnological survey of the main drinking water reservoirs in the Pernambuco State. The present study was conducted in 39 reservoirs during the 1998 drought (September to November), which was a consequence of the strong El Niño event of 1997 (Kerr 1998). The goals of this investigation were to examine, in a special ecological situation, the trophic state of reservoirs and to establish relationships between biological groups and limnological parameters. The study focused primarily on the genus Cylindrospermopsis and the factors favoring its dominance in reservoirs located in the Pernambuco State.

\section{MATERIALS AND METHODS}

Sample collection. The Pernambuco State covers approximately $98307 \mathrm{~km}^{2}$ in the north-eastern part of Brazil. The 39 studied reservoirs are located between $7^{\circ} 28^{\prime} \mathrm{S}$ to $9^{\circ} 07^{\prime} \mathrm{S}$ and $36^{\circ} 44^{\prime} \mathrm{W}$ to $40^{\circ} 33^{\prime} \mathrm{W}$ (Fig. 1, Table 1), and are included in 5 different hydrographic basins. The hydrological balance in this Brazilian region is characterized by an annual precipitation

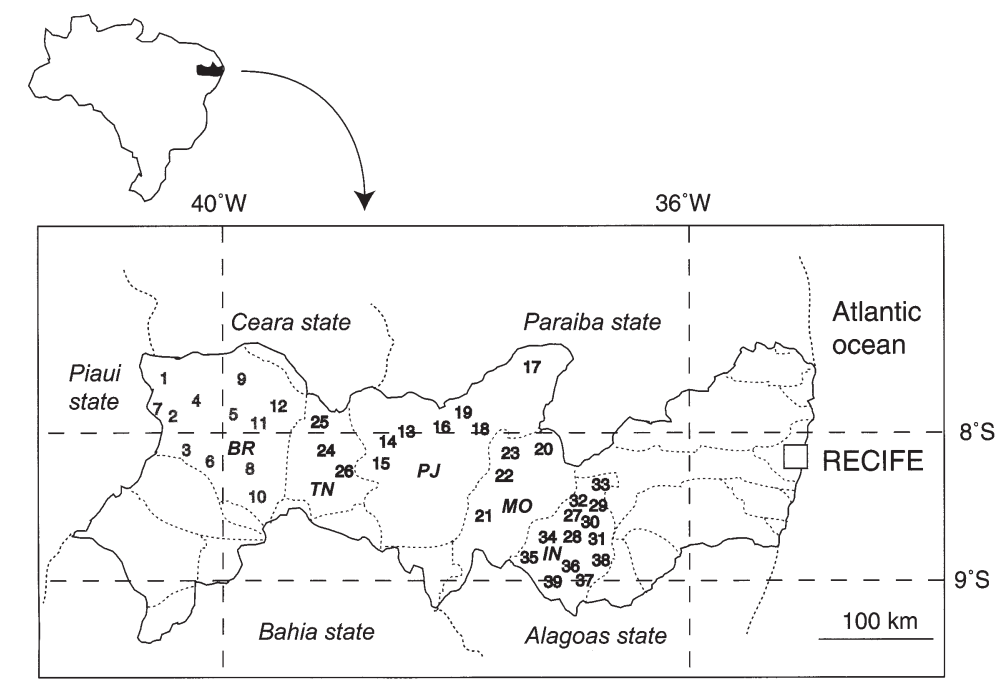

Fig. 1. Map of Pernambuco State (Brazil) and location of the reservoirs sampled in different hydrographic basins during the survey (September to November 1998). See Table 1 for geographical coordinates of each reservoir number. Abbreviations for hydrographic basins: BR, Brigida basin; PJ, Pajeu basin; MO, Moxoto basin; TN, Terra Nova basin; IN, Ipanema basin 
Table 1. List of reservoirs studied in 5 hydrographic basins of the Pernambuco State. Reservoir number, geographical coordinates, maximal water capacity and surface area are reported. (nd: not determined). Faz.: fazenda

\begin{tabular}{|c|c|c|c|c|c|c|}
\hline No. & Code & Reservoir & $\begin{array}{l}\text { Latitude } \\
\text { South }\end{array}$ & $\begin{array}{c}\text { Longitude } \\
\text { East }\end{array}$ & $\begin{array}{c}\text { Water } \\
\text { capacity } \\
\left(\mathrm{Mm}^{3}\right)\end{array}$ & $\begin{array}{c}\text { Area } \\
\text { (ha) }\end{array}$ \\
\hline \multicolumn{7}{|c|}{ Brigida basin } \\
\hline 1 & BR-01 & Araripina & $7^{\circ} 34^{\prime} 34^{\prime \prime}$ & $40^{\circ} 28^{\prime} 20^{\prime \prime}$ & 3.70 & 75 \\
\hline 2 & BR-02 & Rancharia & $7^{\circ} 41^{\prime} 59^{\prime \prime}$ & $40^{\circ} 33^{\prime} 25^{\prime \prime}$ & 1.04 & 32 \\
\hline 3 & BR-03 & Gergelim & $7^{\circ} 48^{\prime} 49^{\prime \prime}$ & $40^{\circ} 29^{\prime} 03^{\prime \prime}$ & 0.03 & nd \\
\hline 4 & BR-04 & Lagõa do Barro & $7^{\circ} 46^{\prime} 13^{\prime \prime}$ & $40^{\circ} 23^{\prime} 02^{\prime \prime}$ & 24.00 & 405 \\
\hline 5 & BR-05 & Lopes II & $7^{\circ} 52^{\prime} 21^{\prime \prime}$ & $39^{\circ} 56^{\prime} 07^{\prime \prime}$ & 23.93 & 760 \\
\hline 6 & BR-06 & Algodões & $7^{\circ} 58^{\prime} 46^{\prime \prime}$ & $40^{\circ} 19^{\prime} 17^{\prime \prime}$ & 58.48 & 1158 \\
\hline 7 & BR-07 & Barriguda & $7^{\circ} 51^{\prime} 44^{\prime \prime}$ & $40^{\circ} 29^{\prime} 33^{\prime \prime}$ & 1.62 & nd \\
\hline 8 & BR-08 & Entremontes & $8^{\circ} 13^{\prime} 43^{\prime \prime}$ & $39^{\circ} 53^{\prime} 49^{\prime \prime}$ & 339.33 & 4605 \\
\hline 9 & BR-09 & Moreilândia & $7^{\circ} 37^{\prime} 46^{\prime \prime}$ & $39^{\circ} 32^{\prime} 16^{\prime \prime}$ & 0.80 & nd \\
\hline 10 & BR-10 & Caiçara & $8^{\circ} 22^{\prime} 01^{\prime \prime}$ & $39^{\circ} 53^{\prime} 30^{\prime \prime}$ & 10.50 & 180 \\
\hline 11 & BR-11 & Cachimbo & $7^{\circ} 59^{\prime} 41^{\prime \prime}$ & $39^{\circ} 45^{\prime} 57^{\prime \prime}$ & 15.00 & 723 \\
\hline 12 & BR-12 & Chapéu & $7^{\circ} 59^{\prime} 39^{\prime \prime}$ & $39^{\circ} 34^{\prime} 06^{\prime \prime}$ & 188.00 & 2615 \\
\hline \multicolumn{7}{|c|}{ Pajeu basin } \\
\hline 13 & PA-01 & Jazigo & $7^{\circ} 59^{\prime} 58^{\prime \prime}$ & $38^{\circ} 14^{\prime} 31^{\prime \prime}$ & 15.54 & 460 \\
\hline 14 & PA-02 & Saco I & $7^{\circ} 56^{\prime} 43^{\prime \prime}$ & $38^{\circ} 17^{\prime} 09^{\prime \prime}$ & 36.00 & 661 \\
\hline 15 & PA-03 & Cachoeira II & $7^{\circ} 58^{\prime} 26^{\prime \prime}$ & $38^{\circ} 19^{\prime} 20^{\prime \prime}$ & 21.03 & 390 \\
\hline 16 & PA-04 & Chinelo & $7^{\circ} 47^{\prime} 01^{\prime \prime}$ & $37^{\circ} 47^{\prime} 25^{\prime \prime}$ & 2.86 & 98 \\
\hline 17 & PA-06 & São José II & $7^{\circ} 28^{\prime} 35^{\prime \prime}$ & $37^{\circ} 17^{\prime} 44^{\prime \prime}$ & 7.15 & 121 \\
\hline 18 & PA-09 & Rosário & $7^{\circ} 46^{\prime} 20^{\prime \prime}$ & $37^{\circ} 28^{\prime} 18^{\prime \prime}$ & 34.99 & 898 \\
\hline 19 & PA-10 & Brotas & $7^{\circ} 44^{\prime} 47^{\prime \prime}$ & $37^{\circ} 37^{\prime} 16^{\prime \prime}$ & 19.64 & 467 \\
\hline \multicolumn{7}{|c|}{ Moxoto basin } \\
\hline 20 & MO-01 & Cachoeira I & $8^{\circ} 04^{\prime} 03^{\prime \prime}$ & $37^{\circ} 13^{\prime} 16^{\prime \prime}$ & 5.95 & 120 \\
\hline 21 & MO-02 & Poço da Cruz & $8^{\circ} 30^{\prime} 31^{\prime \prime}$ & $37^{\circ} 42^{\prime} 17^{\prime \prime}$ & 504.00 & 5610 \\
\hline 22 & MO-03 & Custódia & $7^{\circ} 58^{\prime} 26^{\prime \prime}$ & $38^{\circ} 19^{\prime} 20^{\prime \prime}$ & 21.62 & 390 \\
\hline 23 & $\mathrm{MO}-04$ & Barra & $7^{\circ} 56^{\prime} 43^{\prime \prime}$ & $38^{\circ} 17^{\prime} 09^{\prime \prime}$ & 2.73 & 59 \\
\hline \multicolumn{7}{|c|}{ Terra Nova basin } \\
\hline 24 & TN-02 & Lagoa dos Satã & $7^{\circ} 59^{\prime} 11^{\prime \prime}$ & $39^{\circ} 04^{\prime} 45^{\prime \prime}$ & 0.06 & $<1$ \\
\hline 25 & TN-03 & Barrinha & $7^{\circ} 43^{\prime} 43^{\prime \prime}$ & $39^{\circ} 15^{\prime} 55^{\prime \prime}$ & 1.95 & 46 \\
\hline 26 & TN-04 & Bõa Vista & $8^{\circ} 03^{\prime} 31^{\prime \prime}$ & $39^{\circ} 03^{\prime} 12^{\prime \prime}$ & 16.45 & 270 \\
\hline \multicolumn{7}{|c|}{ Ipanema basin } \\
\hline 27 & IN-01 & Mororó & $8^{\circ} 29^{\prime} 38^{\prime \prime}$ & $36^{\circ} 56^{\prime} 44^{\prime \prime}$ & 2.93 & 42 \\
\hline 28 & IN-02 & Arcoverde & $8^{\circ} 33^{\prime} 33^{\prime \prime}$ & $36^{\circ} 59^{\prime} 07^{\prime \prime}$ & 16.80 & 200 \\
\hline 29 & IN-03 & Alagoinha & $8^{\circ} 29^{\prime} 37^{\prime \prime}$ & $36^{\circ} 44^{\prime} 56^{\prime \prime}$ & 0.02 & nd \\
\hline 30 & IN-04 & Venturosa & $8^{\circ} 34^{\prime} 47^{\prime \prime}$ & $36^{\circ} 52^{\prime} 37^{\prime \prime}$ & 0.12 & nd \\
\hline 31 & IN-05 & Ingazeira & $8^{\circ} 36^{\prime} 48^{\prime \prime}$ & $36^{\circ} 54^{\prime} 23^{\prime \prime}$ & 4.81 & 130 \\
\hline 32 & IN-06 & Ipaneminha & $8^{\circ} 22^{\prime} 05^{\prime \prime}$ & $36^{\circ} 51^{\prime} 32^{\prime \prime}$ & 3.60 & 67 \\
\hline 33 & IN-07 & Tambores & $8^{\circ} 22^{\prime} 30^{\prime \prime}$ & $36^{\circ} 44^{\prime} 08^{\prime \prime}$ & 0.03 & nd \\
\hline 34 & IN-09 & Buíque & $8^{\circ} 37^{\prime} 43^{\prime \prime}$ & $37^{\circ} 10^{\prime} 01^{\prime \prime}$ & 0.11 & nd \\
\hline 35 & IN-10 & Itaíba & $8^{\circ} 55^{\prime} 40^{\prime \prime}$ & $37^{\circ} 25^{\prime} 29^{\prime \prime}$ & 0.44 & 14 \\
\hline 36 & IN-11 & Ipanema & $9^{\circ} 05^{\prime} 16^{\prime \prime}$ & $37^{\circ} 09^{\prime} 33^{\prime \prime}$ & 0.71 & 30 \\
\hline 37 & IN-12 & Faz. Ribeira Alta & $9^{\circ} 07^{\prime} 26^{\prime \prime}$ & $37^{\circ} 01^{\prime} 23^{\prime \prime}$ & nd & nd \\
\hline 38 & IN-13 & Iati & $8^{\circ} 37^{\prime} 68^{\prime \prime}$ & $37^{\circ} 10^{\prime} 01^{\prime \prime}$ & 0.14 & 305 \\
\hline 39 & IN-14 & Faz. Santa Lúcia & $9^{\circ} 01^{\prime} 54^{\prime \prime}$ & $37^{\circ} 17^{\prime} 88^{\prime \prime}$ & nd & nd \\
\hline
\end{tabular}

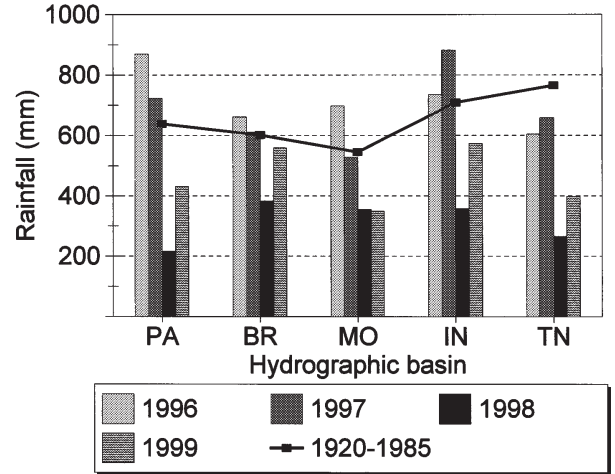

Fig. 2. Annual average precipitation for $4 \mathrm{yr}$ (1996 to 1999) compared to the annual average precipitation for the 1920 to 1985 period for the 5 hydrographic basins studied. For abbreviations see Fig. 1

All of the 39 reservoirs were sampled between September and November 1998, under homogeneous climatic conditions. Most reservoirs were at their lowest levels, with an average reduction in the total water capacity of $86 \%$. Thus, the water volume of the reservoirs ranged between 0.003 and $15 \mathrm{Mm}^{3}$ with an average of $2.19 \mathrm{Mm}^{3}$. The depth of the reservoirs varied between 0.5 and $12 \mathrm{~m}$ with a mean of $3.92 \mathrm{~m}$ (Table 2).

Sampling and analysis procedures. A total of 30 environmental and biological parameters were studied. Sampling was conducted generally before 12:00 $\mathrm{h}$ at the deepest part of each reservoir, near the dam. Vertical profiles of temperature, $\mathrm{pH}$ and dissolved oxygen were recorded at intervals of $0.5 \mathrm{~m}$ from the surface to the bottom, using specific electrodes (YSI probe and $\mathrm{pH}$ probe). Conductivity was measured using a Tacussel conductimeter with the value corrected for temperature. Alkalinity was measured using the titration method (Gran 1952).

Light transparency was assessed routinely using a $30 \mathrm{~cm}$ Secchi disk. The values for the mixing depth $\left(Z_{\text {mix }}\right)$ were obtained from the temperature profiles, and were assumed to correspond to total depth at each sampling station due to the low vertical differences in temperature. The values for the photic zone $\left(Z_{\text {pho }}\right)$ were measured directly using a Li-Cor 193 spherical quantum sensor. In some cases, the values of $Z_{\text {pho }}$ were estimated by multiplying the Secchi disk et al. 2000). 
depth by 2.7 (Margalef 1983). The ratio $Z_{\text {mix }} / Z_{\text {pho }}$ was calculated and used as an index of light limitation (Talling 1971).

Water samples for nutrients, phytoplankton and chlorophyll concentrations were taken with a 21 vertical Niskin bottle at $-0.5 \mathrm{~m}$. The samples for nutrient determinations $\left(\mathrm{NH}_{4}-\mathrm{N}, \mathrm{NO}_{3}-\mathrm{N}, \mathrm{NO}_{2}-\mathrm{N}, \mathrm{PO}_{4}-\mathrm{P}\right)$ were previously filtered though Whatman GF/F fiberglass filters, stored at $-20^{\circ} \mathrm{C}$ and analyzed according to Strickland \& Parsons (1972). Seston weights were determined on preweighed Whatman GF/F filters. After filtration, filters were dried at $65^{\circ} \mathrm{C}$ for $48 \mathrm{~h}$ and reweighed. Particulate phosphorus was measured as for the $\mathrm{PO}_{4}$-P determinations on material collected on pre-combusted Whatman GF/F filters, after hot persulfate digestion in acid conditions (Koroleff 1976). Particulate organic carbon and nitrogen were detected using a CHN analyzer from samples retained on pre-combusted GF/F filters.

Samples for bacterial direct counts were fixed with buffered formalin (2\% final concentration), and stained with DAPI fluochrome (Porter \& Feig 1980). Bacterial cells were counted by epifluorescence microscopy, and mean bacterial volumes were determined by measurements of up to 100 cells using photographic slides and a digitizing table. Cell volumes were calculated using the formula described by Krambeck et al. (1981).

Water samples for chlorophyll analysis were filtered onto Whatman GF/F filters and stored in liquid nitrogen. Chlorophyll a concentrations were determined fluorometrically after methanol extraction (Yentsch \& Menzel 1963). Water samples for phytoplankton analysis were immediately preserved in Lugol's iodine solution, and stored in dark and cold conditions $\left(4\right.$ to $6^{\circ} \mathrm{C}$ ). After sedimentation (for $24 \mathrm{~h}$, chambers of $2 \mathrm{ml}$ for the dominant species, and $10 \mathrm{ml}$ for other algae), phytoplankton species were enumerated by inverted microscopy (Utermöhl's method) in random fields.

Zooplankton was sampled with conical nets $(30 \mathrm{~cm}$ diameter aperture, $80 \mathrm{~cm}$ height, $50 \mu \mathrm{m}$ mesh size). The net was laid on the bottom and hauled 5 min later. The samples were preserved in buffered formaldehyde at $5 \%$ final concentration. Organisms were counted on the whole sample or on subsamples determined volumetrically using wide bore piston pipettes ( 0.5 to $5 \mathrm{ml}$ ) and including at least 300 individuals.

Data processing. Relationships between environmental parameters and biological variables were studied using multivariate analysis. For this type of analysis, all the parameters and variables used must be independent; thus, we suppressed 1 environmental parameter $\left(Z_{\text {mix }} / Z_{\text {pho }}\right)$ and 2 biological variables (total density of phytoplankton and zooplankton). Furthermore, data were not complete for 5 reservoirs and thus the statistical analysis was performed with 34 reservoirs. One principal component analysis (centered PCA) was performed for each of 2 considered data sets: an Environmental System based on 15 parameters, and a Biological System based on 12 variables. The results of the 2 analyses were associated through a co-inertia analysis, which enables the simultaneous analysis of 2 tables having a different number of environmental variables, species, and/or samples (Dolédec \& Chessel 1994). Two sets of factor scores are obtained for the sampling points: scores of the rows 'seen by the environmental parameters', and scores of the rows 'seen by the biological variables'. The significance of the coinertia analysis was tested after a randomization of the results, which consists of a repeated random permutation of the rows of both tables, and a comparison of these results obtained with the normal PCA. The resulting distribution of 2000 replicated matches of 2 arrays gave a highly significant test $(\mathrm{p}<0.001)$. Cluster classification of observation scores from the first factorial planes of the co-inertia analysis (Ward's criterion aggregation) was performed to classify the lakes. All this data processing was performed using ADE-4 software (Thioulouse et al. 1997).

\section{RESULTS}

\section{Environmental parameters}

The reservoirs are shallow (depth mean of $3.9 \mathrm{~m}$ ) and very turbid, with Secchi depths always less than $1 \mathrm{~m}$ (mean of $34 \mathrm{~cm}$; Table 2). Surface temperatures ranged from 23.3 to $32.6^{\circ} \mathrm{C}$ with an average of $26.3^{\circ} \mathrm{C}$. Water temperature near the bottom (data not shown) showed a lower range (from 21.8 to $28^{\circ} \mathrm{C}$ ) with an average of $25.0^{\circ} \mathrm{C}(\mathrm{CV} \%: 4.77 \%)$. Most of the reservoirs (35 reservoirs, approx. $90 \%$ ) were not thermally stratified, with a difference $<2{ }^{\circ} \mathrm{C}$ between the surface and the bottom. The $Z_{\text {mix }} / Z_{\text {pho }}$ mean was high (5.47), with most values ranging between 2 and 10; higher values (14.8 and 36.6 ) in 2 of the reservoirs (Nos. 2 and 30) were characterized by high suspended inorganic material (Secchi depths of $5 \mathrm{~cm}$ ). pH values ranged between 6.7 and 9 at surface level, with most of the values (25 reservoirs, approx. $64 \%$ ) above 8 . Near the bottom, $\mathrm{pH}$ values were similar, with a mean difference of 0.47 with the surface values (data not shown). Average total alkalinity was high $\left(2096 \mu \mathrm{Eq} \mathrm{l^{-1 }}\right)$, with the highest value close to $5500 \mu \mathrm{Eq} \mathrm{l^{-1 }}$ (No. 14). Conductivity ranged from 198 to $25000 \mu \mathrm{S} \mathrm{cm}{ }^{-1}$, with high values (>10000 $\mu \mathrm{S}$ $\mathrm{cm}^{-1}$ ) in 3 reservoirs (Nos. 14, 20 and 29) located in 3 different hydrographic basins. Most values (95\%) were $<4000 \mu \mathrm{S} \mathrm{cm}{ }^{-1}$ and $50 \%$ were $<1500 \mu \mathrm{S} \mathrm{cm} \mathrm{cm}^{-1}$ (Table 2). 


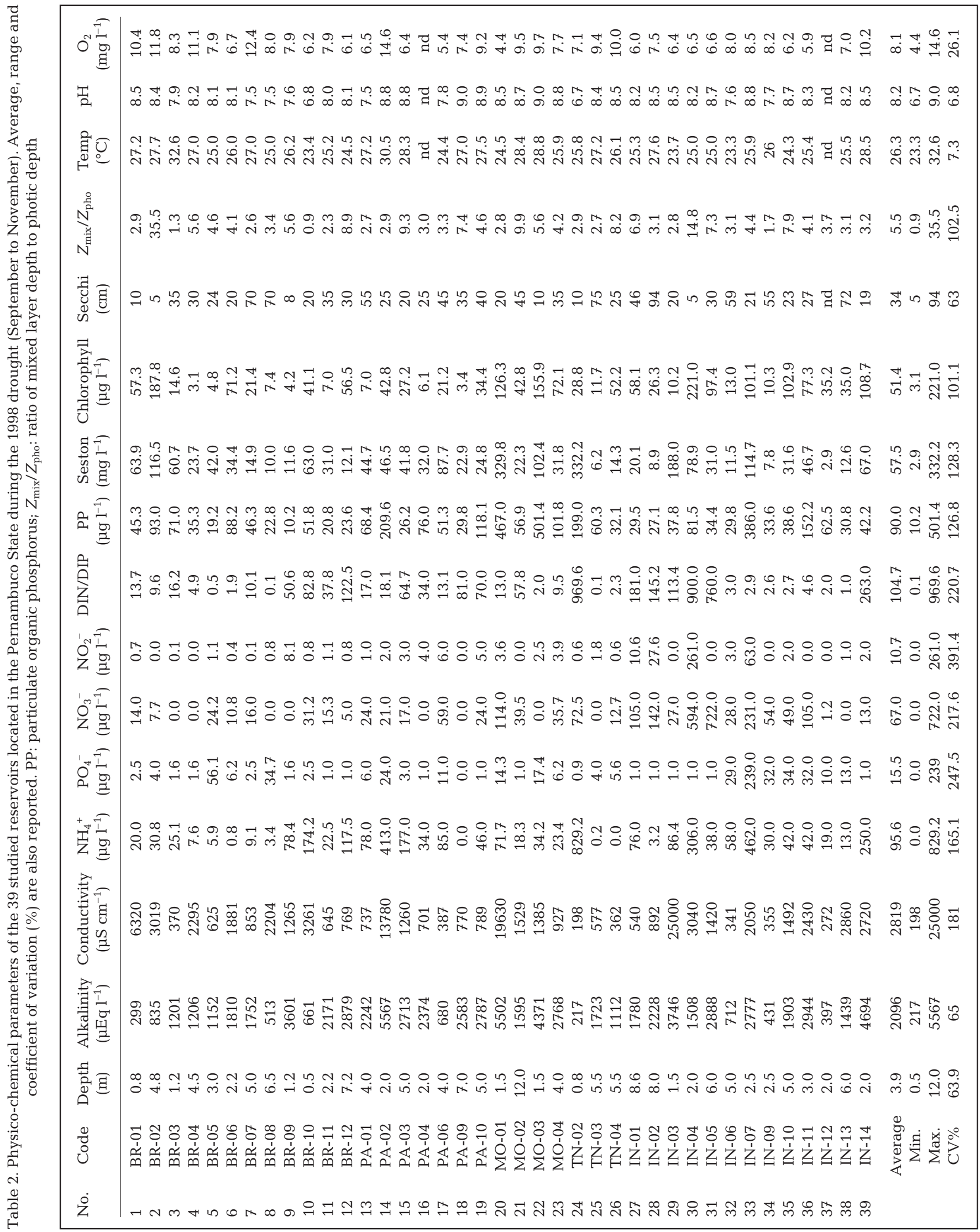


Dissolved nutrient concentrations showed high variation ranges, with ammonium representing the larger contribution of nitrogen forms. Nitrogen concentrations presented high means, with $95.6 \mu \mathrm{g} \mathrm{l}^{-1}$ for ammonia and $67 \mathrm{\mu g} \mathrm{l}^{-1}$ for nitrate. Five shallower reservoirs showed ammonia concentrations $>200 \mu \mathrm{g} \mathrm{l}^{-1}$ (Nos. 14, $24,30,33$, and 39). One reservoir (No. 30) showed the

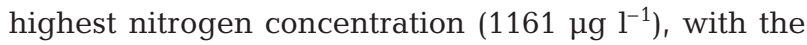
uniquely high value of nitrite $\left(261 \mathrm{\mu g} \mathrm{l}^{-1}\right)$, confirming the high degree of eutrophication of this reservoir which directly receives all the domestic and industrial sewage. Dissolved phosphorus concentrations showed low values (mean of $15.5 \mathrm{\mu g} \mathrm{l}^{-1}$ ) except for 1 value (239 $\mu \mathrm{g}^{-1}$; No. 33). The dissolved inorganic N/P weight ratio averaged 104.7 with a great range of variation, and $54 \%$ of reservoirs showed a ratio $<20$. (Table 2 ).

Particulate organic phosphorus showed a high average $\left(90 \mu \mathrm{g} \mathrm{l}^{-1}\right)$, with the highest values corresponding generally to those of the seston weight (close to $330 \mathrm{mg}$ $\mathrm{I}^{-1}$; Nos. 20 and 24). Particulate organic nitrogen averaged $2.3 \mathrm{mg} \mathrm{N} \mathrm{I}^{-1}$ (range from 0.2 to 12.0 ) while particulate organic carbon averaged $13.5 \mathrm{mg} \mathrm{C} \mathrm{l}^{-1}$ (range from 1.7 to 66.9). Chlorophyll concentration, considered here as an environmental trophic index, was generally high (mean of $51.4 \mathrm{\mu g} \mathrm{l}^{-1}$ ) with 3 values up to $150 \mathrm{\mu g} \mathrm{l}^{-1}$ (Nos. 2, 22 and 30). Only 6 reservoirs (15\%) showed low chlorophyll concentrations $\left(<10 \mu \mathrm{g} \mathrm{l}^{-1}\right)$.

\section{Biological variables}

Bacterial density varied from $2.3 \times 10^{9}$ to $7.4 \times 10^{10}$ cells $\mathrm{l}^{-1}$ (Table 3 ) with a coefficient of variation $<100 \%$, suggesting a great spatial homogeneity for this variable in the studied reservoirs. The highest density was found in the reservoir (No. 20) showing high chlorophyll $a$ and particulate phosphorus concentrations. Little difference in bacteria size (biovolume) was observed across reservoirs, with a mean cell volume for the entire data set of $0.051 \mathrm{\mu m}^{3}$. Only 3 reservoirs (Nos. 13, 18 and 20) showed bacterial biovolume $>0.100 \mathrm{\mu m}^{3}$.

A total of 202 taxa, belonging to 5 algal classes, were identified in the phytoplankton assemblages in the studied reservoirs (Pereira et al. 1999). Phytoplankton density ranged from $3 \times 10^{4}$ to $3 \times 10^{9}$ cells l$^{-1}$ with a great coefficient of variation ( $351 \%$; Table 3 ). Chlorophyceae was the most prominent group in terms of species number (73 taxa). However, in terms of abundance and biomass (biomass data not shown) cyanobacteria dominated the phytoplankton community across the reservoirs, representing on average $63.5 \%$ of algal numbers. The filamentous cyanobacterium Cylindrospermopsis represented $42.6 \%$ of the total algal density for the entire data set (Table 3, Fig. 3).
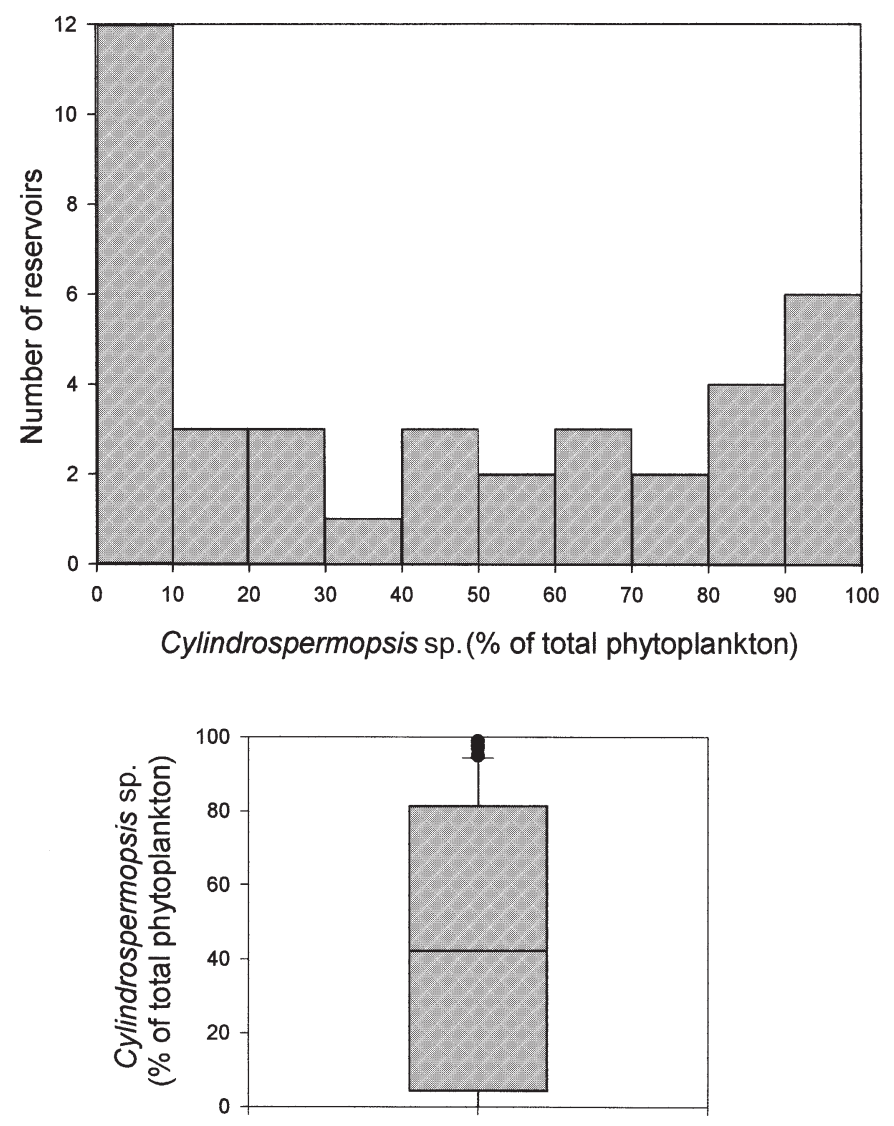

Fig. 3. Distribution and scatter plots of the cyanobacterium Cylindrospermopsis sp. percentages of total phytoplankton in the 39 reservoirs studied

The morphological characteristics of naturally occurring populations of the various forms of Cylindrospermopis are not shown in this study. However, with a mean length of trichomes close to $100 \mu \mathrm{m}(\mathrm{n}=204)$, the abundance of the trichomes reported here may represent a great proportion of the biomass, as demonstrated in previous studies (Bouvy et al. 1999, Nascimento et al. 2000). The genus Cylindrospermopsis occurred in 31 reservoirs ( $80 \%$ ) and represented more than $50 \%$ of the total phytoplankton density in 17 reservoirs $(43 \%)$, and more than $90 \%$ of the total density in 6 reservoirs (Nos. 15, 22, 23, 31, 35, and 36). Bacillariophycea were detected in 33 reservoirs in low proportions (total mean of 9.9\%), except for 1 reservoir (No. 9) with $69 \%$ of total algal density. The other algal classes were present in lower numbers, with an average between 2.6 and $3.9 \%$ of the total density (Table 3 ).

A total of 41 zooplankton taxa were identified, belonging to 3 common groups: Rotifera included 26 taxa with 10 species of Brachionus, among which $B$. calyciflorus, B. plicatilis and B. fulcatus dominated. Copepoda comprised 8 taxa with Cyclopoida (Mesocy- 


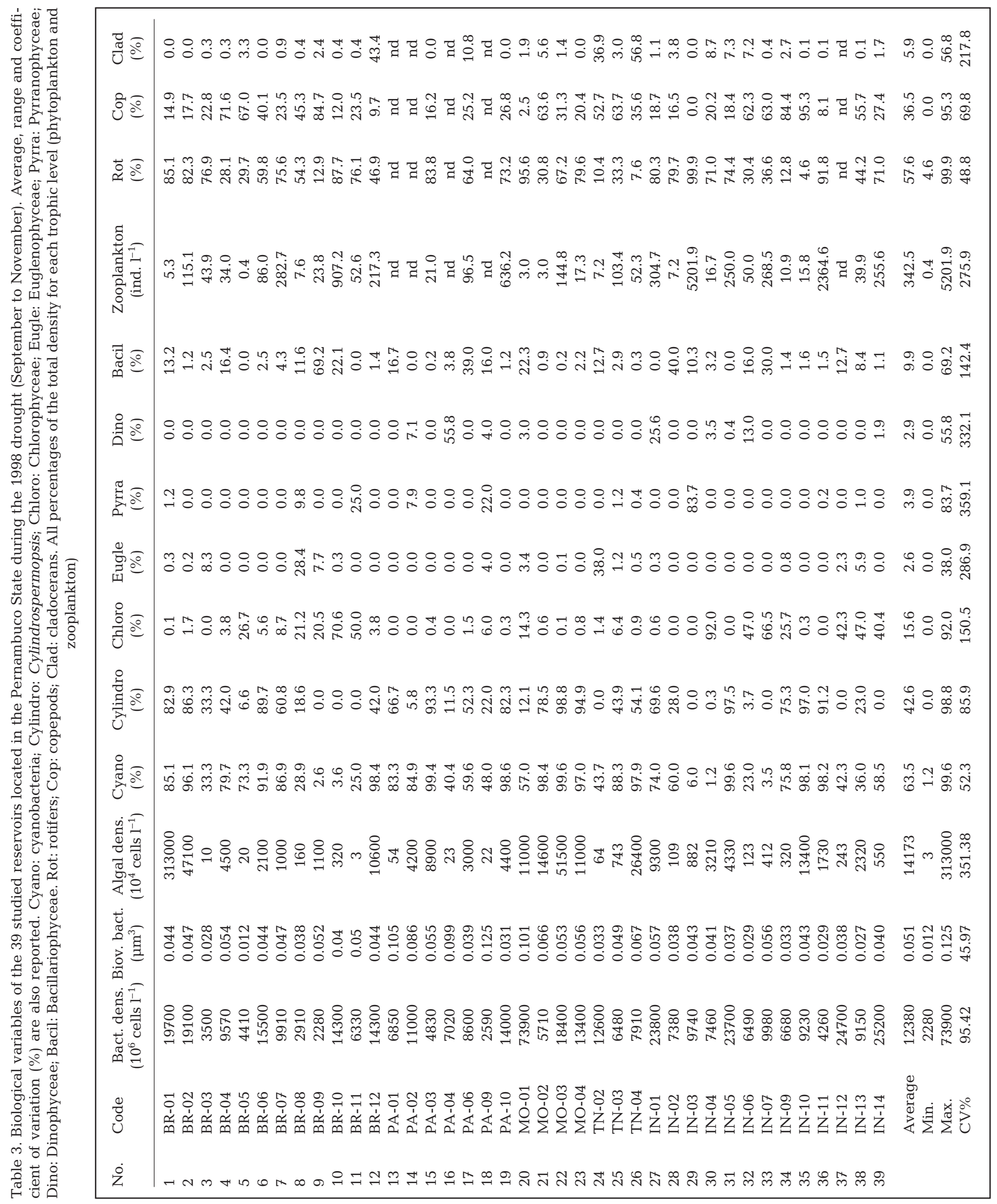


clops spp. and Thermocyclops spp.) and Calanoida (Notodiaptomus spp.) being dominant. Cladocera included 7 taxa with an abundance of Diaphonosoma excisum, Moina micrura and Ceriodaphnia cornuta (data not shown). In this study zooplankton data are analyzed only in terms of total numbers and percentages of rotifers, copepods and cladocerans. Zooplankton numbers varied from 0.4 to 5202 ind. $^{-1}$ with an average of $342 \mathrm{ind}^{-1} \mathrm{l}^{-1}$ (Table 3 ). Only 4 reservoirs showed densities $>500$ ind. $\mathrm{l}^{-1}$ (Nos. 10, 19, 29, and 36). Rotifers dominated the zooplankton community with a mean of $57.6 \%$ of total density, and reached percentages up to $90 \%$ in 3 reservoirs (Nos. 20, 29, and 36). Copepods represented the second most important group in terms of abundance, with a mean of $36.5 \%$. With an average percentage of $5.9 \%$, cladocerans represented a minor fraction of the zooplankton community, and were only present with percentages $>10 \%$ in 4 reservoirs (Nos. 12, 17, 24, and 26).

\section{Co-inertia analysis}

The 2 PCAs on environmental and biological variables were performed on the whole data sets (34 reservoirs; 15 environmental parameters, 12 biological variables). The first 2 eigenvalues of the co-inertia analysis accounted for $75.5 \%$ of the total variability (Figs. 4A \& 5A). Thus the analysis focused on the first 2 axes. The values of the projected variances of the Environmental and Biological tables on the axes (F1, F2) of the coinertia analysis (Iner E and Iner B) were close to the values of projected variances of the same tables on the same axes of the standard (PCA) analysis (Var E and Var B) (Table 4). The factorial plane of the co-inertia for the Biological table explained $89.7 \%$ of the variance, and the factorial plane for the Environmental table explained $86.4 \%$ of the variance. Hence, the co-inertia analysis was able to demonstrate a costructure between the 2 data sets. Figs. 4 \& 5 represent the factorial planes of the variables (columns) and of the reservoirs (lines) in the Environmental System and the Biological System, respectively.
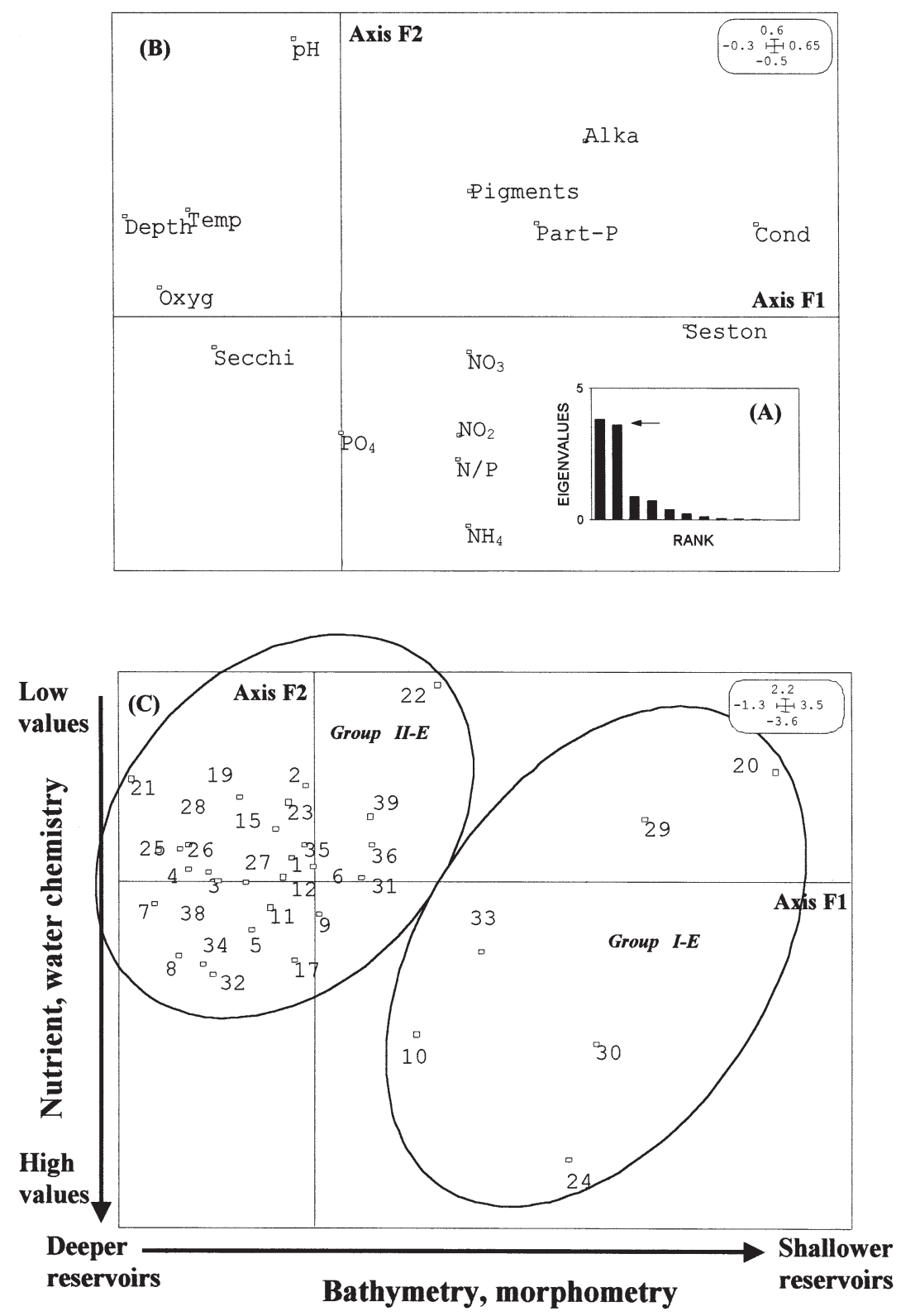

Fig. 4. Co-inertia analysis. (A) (inset) Histogram of eigenvalues demonstrating the prominence of the 2 first axes. (B) Position of the environmental parameters on the F1 $\times$ F2 co-inertia plane. (C) Position of the reservoirs on the F1 $\times$ F2 co-inertia plane, using environmental parameters co-inertia weights, with identification of 2 groups of reservoirs (Ward's criterion aggregation). Depth: reservoir depth; Alka: alkalinity; Cond: conductivity; $\mathrm{NH}_{4}$ : ammonia; $\mathrm{PO}_{4}$ : dissolved phosphorus; $\mathrm{NO}_{3}$ : nitrate $\mathrm{NO}_{2}$ : nitrite; Part-P: particulate phosphorus; seston: suspended material; Pigments: chlorophyll $a_{\text {; }}$ Secchi: depth of Secchi disk; Temp: temperature; Oxyg: dissolved oxygen. See also Table 5

In the Environmental System, conductivity and seston were opposed to reservoir depth and Secchi depth on the first axis (F1; Fig. 4). The second axis (F2) showed an opposition between the nutrient context $\left(\mathrm{NH}_{4}, \mathrm{PO}_{4}, \mathrm{~N} / \mathrm{P}, \mathrm{NO}_{3}, \mathrm{NO}_{2}\right)$ and the $\mathrm{pH}$ conditions. The Ward's aggregation recognized 2 groups of reser- 

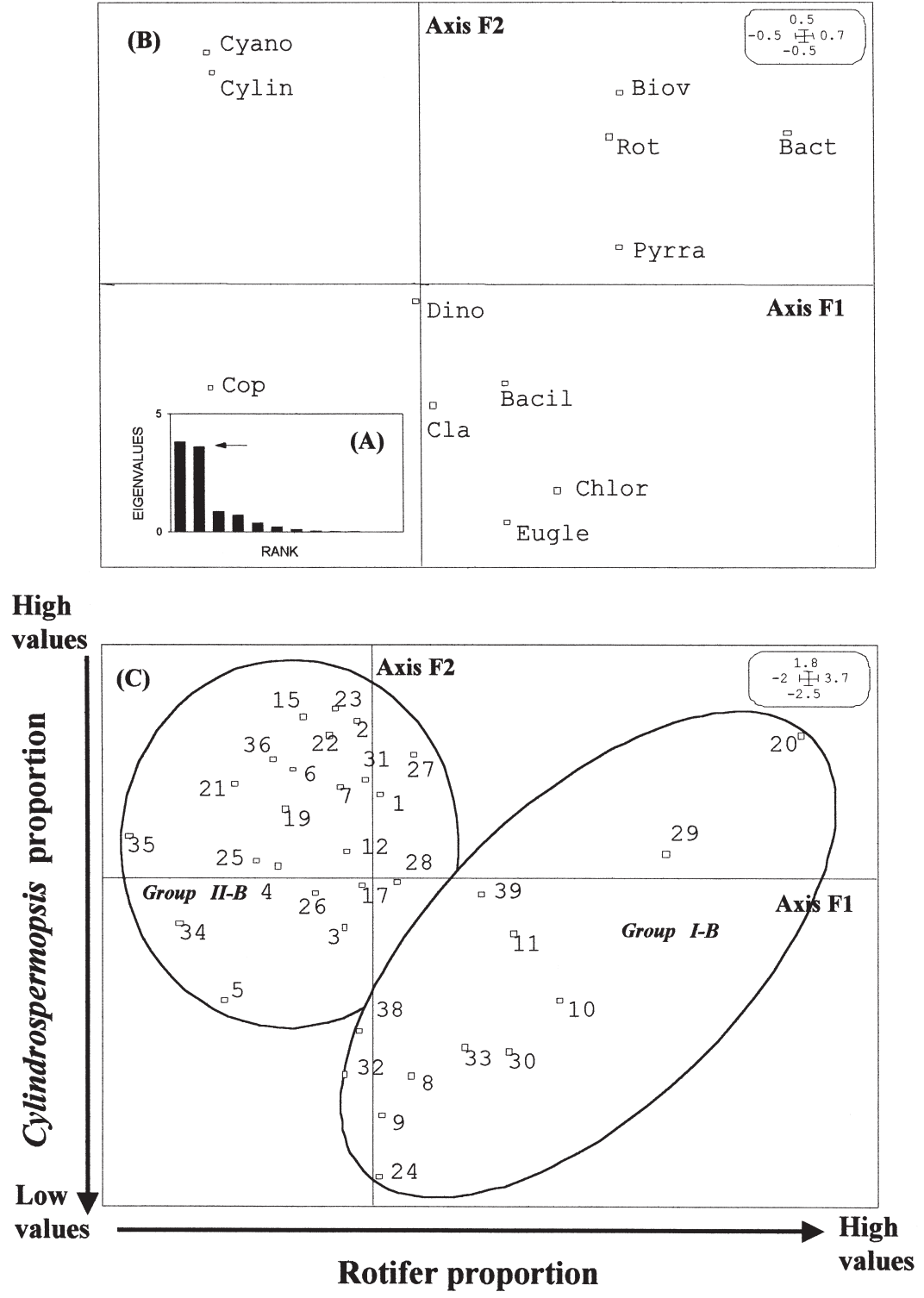

Fig. 5. Co-inertia analysis. (A) (inset) Histogram of eigenvalues demonstrating the prominence of the 2 first axes. (B) Position of the biological variables on the F1 × F2 co-inertia plane. (C) Position of the reservoirs on the F1 $\times$ F2 coinertia plane, using biological variables co-inertia weights, with identification of 2 groups of reservoirs (Ward's criterion aggregation). Bact: total bacteria; Biov: bacterial biovolume; Cyano: Cyanobacteria; Cylin: Cylindrospermopsis; Chlor: Chlorophyceae; Eugle: Euglenophyceae; Pyrra: Pyrranophyceae; Bacil: Bacillariophyceae; Rot: rotifers; Cop: copepods; Cla: cladocerans. See also Table 5

voirs. The first group (I-E) comprised 6 reservoirs (Nos. 10, 20, 24, 29, 30, and 33). The reservoirs of the second group (28 reservoirs; II-E) had significantly higher depth, higher Secchi depth, lower concentrations of ammonia and nitrate, and lower concentrations of particulate phosphorus and suspended mater- ial (Table 5). Consequently, the factorial plane defined by the first 2 axes in this environmental system arranges reservoirs according to 2 gradients based on bathymetry (Axis F1) and nutrient richness (Axis F2).

In the Biological System F1 showed the association of the rotifers (Rot) and the bacterial densities (Bact), opposed to the copepod abundances (Fig. 5). In addition, the presence of rotifers appeared to be linked to the bacterial biovolume (Biov). F2 showed the opposition of Cylindrospermopsis and cyanobacteria with the other algal groups (Euglenophyceae, Chlorophyceaea, Bacillariophyceae). In this system, Ward's classification produced by cluster analysis on the scores of reservoirs recognized 2 main groups: I-B (12 reservoirs) and II-B (22 reservoirs). Group I-B included the reservoirs of Group I-E from the Environmental System. The reservoirs of Group II-B had significantly higher percentages of Cyanobacteria and Cylindrospermopsis, and lower densities of Chlorophyceae, Euglenophyceae, and Bacillariophyceae than those observed in the reservoirs of Group IB (Table 5). No obvious pattern in spatial distribution of reservoirs (e.g. according to hydrographic basins) can be reported for the reservoirs containing Cylindrospermopsis. Thus the mean values of biological characteristics in the 2 groups of reservoirs varied along gradients based on rotifer (Axis F1) and Cylindrospermopsis proportion (Axis F2).

Finally, the correlation between the new environmental and biological ordination of the reservoirs which reflects the degree of association between the 2 systems (Environment and Biology) was highly significant, with R-values of 0.769 and 0.782 for the 2 factorial planes (Axis F1 Environment/Axis F1 Biology; Axis F2 Environment/Axis F2 Biology). All these results illustrate a good fit between the 2 new ordination sets, allowing us to draw some conclusions about the occurrence of Cylindrospermopsis and the environmental conditions in the reservoirs studied. 


\section{DISCUSSION}

\section{Trophic state of the reservoirs}

Several comparative studies have demonstrated that eutrophication affects phytoplankton structure of dif-

Table 4. Comparison of inertia from the 2 data sets based on Environmental (E) and Biological (B) variables resulting from the co-inertia analysis. Two co-inertia axes (F1 and F2) are selected. Var E and Var B: inertia of each table projected on the co-inertia axes. Iner E and Iner B: maximal projected inertia of each table. Covar: covariance of the 2 sets of coordinates projected on the co-inertia axes. R-value represents the correlation between the 2 new sets of coordinates resulting from the co-inertia analysis

\begin{tabular}{|lcccccc|}
\hline Axis & Var E & Var B & Iner E & Iner B & Covar & R-value \\
\hline F1 & 3.39 & 2.15 & 4.04 & 2.83 & 1.96 & 0.724 \\
F2 & 2.18 & 2.58 & 2.41 & 2.46 & 1.90 & 0.800 \\
& & & & & & \\
\hline
\end{tabular}

ferent types all over the world (Sommer et al. 1986, Nixdorf \& Deneke 1997, Reynolds 1998), leading sometimes to local loss of diversity with the explosion of a few species with high abundance (Talling \& Lemoalle 1998). To evaluate the trophic characterization of an aquatic system, many trophic indexes have been developed for temperate regions (Carlson 1977 , Forsberg \& Ryding 1980). The relationship between total phosphorus and chlorophyll a concentrations has been used as a surrogate for grades of eutrophication (OECD 1982). The application of this standard relationship to our data revealed that $90 \%$ of the investigated sites would be classified as eutrophic-hypertrophic (Fig. 6), and we conclude that it is not appropriate to establish a trophic classification presenting the standard rigid trophic divisions. This conclusion corroborates those drawn by Huszar et al. (2000) about the use of temperate criteria for the classification of tropical ecosystems. The adoption of criteria that are related to the ecological aspect of the tropical water bodies is necessary. Changes in community composi-

Table 5. Average characteristics of the 2 main groups of reservoirs, I and II, defined for each system (Environmental [E] and Biological [B]) after co-inertia analysis for environmental parameters and biological variables (Ward's criterion aggregation). Differences between groups were tested using the non-parametric Mann-Whitney $U$-test $\left({ }^{*} \mathrm{p}<0.05 ;{ }^{* *} \mathrm{p}<0.01 ; \mathrm{ns}=\mathrm{p}>0.05\right)$

\begin{tabular}{|c|c|c|c|c|c|c|c|}
\hline & \multicolumn{5}{|c|}{ Mean values } & \multicolumn{2}{|c|}{ Differences } \\
\hline & \multirow{3}{*}{$\begin{array}{l}\text { System: } \\
\text { Groups: } \\
\text { N values: }\end{array}$} & \multicolumn{2}{|c|}{$\mathrm{E}$} & \multicolumn{2}{|c|}{ B } & \multirow{3}{*}{$\begin{array}{c}\text { E } \\
\text { I-E / II-E }\end{array}$} & \multirow{3}{*}{$\begin{array}{c}\text { B } \\
\text { I-B / II-B }\end{array}$} \\
\hline & & I-E & II-E & I-B & II-B & & \\
\hline & & 6 & 28 & 12 & 22 & & \\
\hline \multicolumn{8}{|l|}{ Environmental parameters } \\
\hline Depth $(\mathrm{m})$ & & 1.47 & 4.66 & 2.64 & 4.74 & ** & * \\
\hline Alkalinity $\left(\mu E q l^{-1}\right)$ & & 2683 & 1845 & 2295 & 1866 & ns & ns \\
\hline Conductivity $\left(\mu \mathrm{S} \mathrm{cm}^{-1}\right)$ & & 4927 & 1449 & 3473 & 1395 & ns & ns \\
\hline Ammonia $\left(\mu \mathrm{g} \mathrm{l}^{-1}\right)$ & & 280 & 49.7 & 200 & 41.1 & ** & ** \\
\hline Dissolved phosphorus $\left(\mu \mathrm{g}^{-1}\right)$ & & 40.5 & 10.1 & 30.1 & 9.51 & ns & ns \\
\hline Dissolved nitrate $\left(\mu \mathrm{g} \mathrm{l}^{-1}\right)$ & & 150.9 & 59.6 & 90.2 & 71.3 & $*$ & ns \\
\hline Dissolved nitrite $\left(\mu \mathrm{g} \mathrm{l}^{-1}\right)$ & & 50.1 & 15.2 & 30.5 & 9.91 & ns & ns \\
\hline DIN/DIP & & 297 & 68.5 & 203 & 67.9 & ns & ns \\
\hline Particulate phosphorus $\left(\mu g \mathrm{l}^{-1}\right)$ & & 246 & 49.6 & 115 & 76.6 & $* *$ & ns \\
\hline Seston weight $\left(\mathrm{mg} \mathrm{l}^{-1}\right)$ & & 172.7 & 32.8 & 104 & 38.4 & ** & ns \\
\hline Total chlorophyll a $\left(\mu \mathrm{g} \mathrm{l}^{-1}\right)$ & & 97.7 & 45.4 & 58.6 & 54.8 & ns & ns \\
\hline Secchi depth (cm) & & 15.1 & 38.8 & 30.5 & 36.1 & ${ }^{* *}$ & ns \\
\hline Surface temperature $\left({ }^{\circ} \mathrm{C}\right)$ & & 25.3 & 26.4 & 25.2 & 26.7 & ns & $* *$ \\
\hline $\mathrm{pH}$ & & 8.04 & 8.22 & 7.88 & 8.35 & ns & ${ }^{*}$ \\
\hline Dissolved oxygen $\left(\mathrm{mg} \mathrm{l}^{-1}\right)$ & & 7.04 & 8.21 & 7.41 & 8.29 & ns & ns \\
\hline \multicolumn{8}{|l|}{ Biological variables } \\
\hline Total bacteria (cells $\mathrm{l}^{-1}$ ) & & $2.1 \times 10^{10}$ & $1.1 \times 10^{10}$ & $1.5 \times 10^{10}$ & $1.1 \times 10^{10}$ & ns & ns \\
\hline Bacterial biovolume $\left(\mu \mathrm{m}^{3}\right)$ & & 0.054 & 0.047 & 0.051 & 0.048 & ns & ns \\
\hline Cyanobacteria (\%) & & 29.8 & 72.2 & 23.6 & 85.8 & ns & ** \\
\hline Cylindrospermopsis (\%) & & 15.9 & 53.6 & 4.81 & 60.1 & $*$ & ** \\
\hline Chlorophycea $(\%)$ & & 34.9 & 11.6 & 39.2 & 4.00 & ns & ** \\
\hline Euglenophycea (\%) & & 5.96 & 1.98 & 6.97 & 0.53 & ns & ns \\
\hline Pyrranophyceae (\%) & & 0.00 & 1.44 & 2.98 & 0.14 & ns & ns \\
\hline Dinophyceae (\%) & & 0.93 & 1.52 & 1.79 & 1.18 & ns & ns \\
\hline Bacillariophyceae (\%) & & 12.9 & 8.86 & 16.4 & 6.05 & ns & $*$ \\
\hline Rotifers (\%) & & 66.9 & 55.1 & 57.5 & 57.6 & ns & ns \\
\hline Copepods (\%) & & 25.9 & 39.2 & 37.4 & 35.9 & ns & ns \\
\hline Cladocerans (\%) & & 7.11 & 5.62 & 5.04 & 6.41 & ns & ns \\
\hline
\end{tabular}




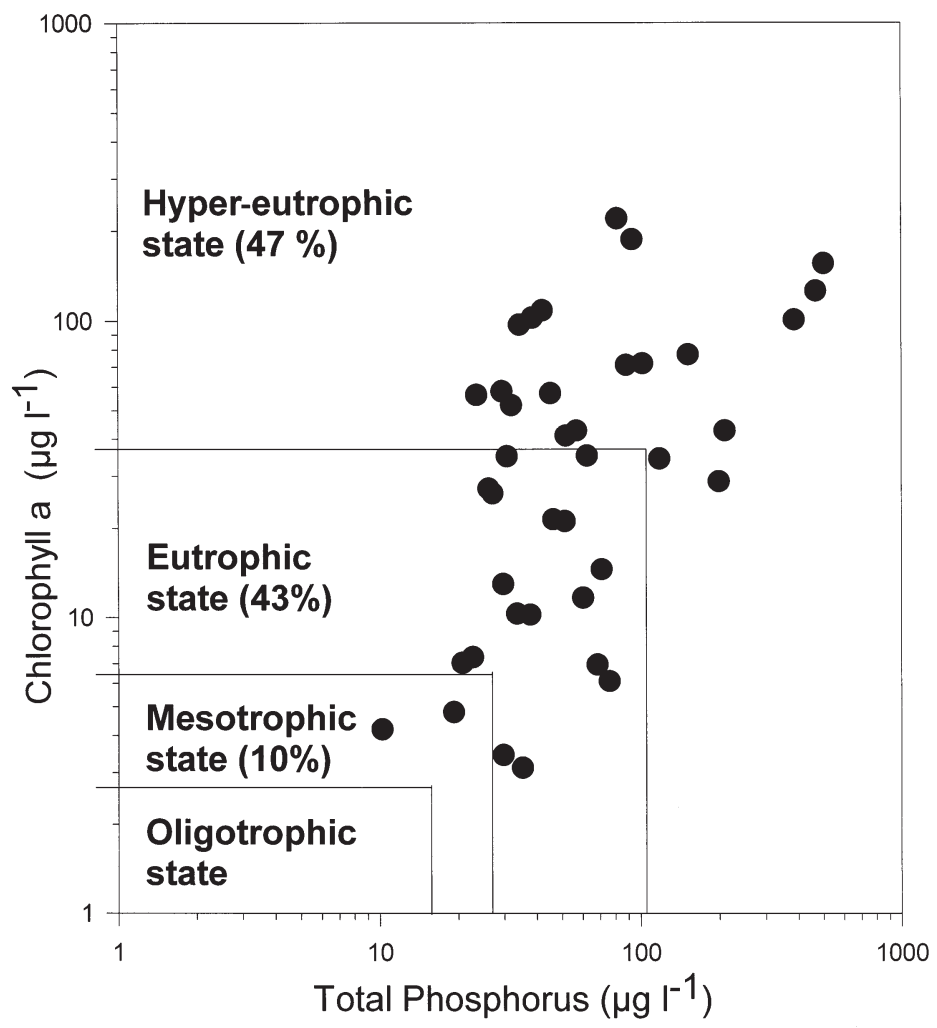

Fig. 6. Trophic relationship of total phosphorus concentrations $\left(\mu \mathrm{g}^{-1}\right)$ versus chlorophyll a concentrations $\left(\mu \mathrm{g} \mathrm{l}^{-1}\right)$ of the reservoirs studied. Axes are $\log _{10}$. Trophic delineation according to Forsberg \& Ryding (1980)

tion can be viewed as being reflected by the strategies of populations, and according to Huszar et al. (1998), the phytoplankton assemblage appears more adequate to define the trophic state in tropical regions.

In our survey, the observed dominance of Cylindrospermopsis is remarkable and has never been reported on this spatial scale. A crucial problem is to elucidate the obvious doubt about the different morphological properties of Cylindrospermopsis. A large degree of variability in filament morphology is well documented for C. raciborskii (Komárková et al. 1999) and a misinterpretation of the 3 species filaments (C. raciborskii, C. philippinensis and C. catemaco) without heterocytes and akinetes is easily possible (Komárková-Legnerová \& Tavera 1996). In a recent report, Huszar et al. (2000) concluded that Cylindrospermopsis was the most important heterocytic genus in 5 north-eastern reservoirs, with 3 species (C. raciborskii, C. philippinensis and $C$. catemaco) being the most dominant. Unfortunately these authors did not provide any morphological descriptions or ecological explanations. For these reasons, in this investigation, we have decided to consider only the genus Cylindrospermopsis. However, over a 2 yr survey in Ingazeira reservoir, Bouvy et al. (1999) reported that an average of $97 \% C$. raciborskii had coiled filaments, with a mean proportion of $12.3 \%$ having terminal heterocytes. Huszar et al. (2000) confirmed this low proportion of Cylindrospermopsis filaments carrying heterocytes (10\%) from north-eastern reservoirs. Only the species C. raciborskii is usually described as an invasive species (Padisák 1997), and is defined as an Sn species due to its low light requirement (Padisák \& Reynolds 1998). This species can represent up to $100 \%$ of the total algal density and biomass under certain environmental conditions (Bouvy et al. 1999, Borics et al. 2000). Although Huszar et al. (1998) and Reynolds (1998) reported that cyanobacteria can represent an important part of phytoplankton in non-eutrophic tropical environments, the single-species community structure is probably the ultimate manifestation of hypertrophy in the studied reservoirs. The success of cyanobacteria in turbid shallow lakes suggests a consistent outcome to similarly selective processes such as light, insolation, buoyancy and size as protection against grazers (Reynolds 1994). In our study, the genus Cylindrospermopsis occurred in 31 reservoirs and represented more than $50 \%$ of the total algal density in 17 reservoirs. Co-inertia analysis clearly shows that the presence of Cylindrospermopsis is linked to typical ambient conditions.

\section{Environmental context}

According to the Environmental System in the coinertia analysis (Fig. 4), temperature, $\mathrm{pH}$ and nutrient concentrations were the most important features correlated with the distribution of phytoplanktonic species, especially Cylindrospermopsis. Temperature (always $>23^{\circ} \mathrm{C}$ ) does not play a major role as it does in temperate zones (e.g. Couté et al. 1997, Padisák 1998), but nevertheless the dominance of Cylindrospermopsis was recorded in the warmer reservoirs. No thermic stratification was detected in our reservoirs, confirming the absence of thermal stratification observed by Bouvy et al. (1999) in Ingazeira reservoir over 2 yr. However, other physical factors can potentially influence the development and dominance of cyanobacteria, such as limitation by light, weather conditions and turbulence (Paerl 1988). The ratio $Z_{\text {mix }} / Z_{\text {pho }}$ was used as an index of light limitation, but due to the linear function between this ratio and Secchi disk depth, this parameter was not included in the co-inertia analysis. However, a significant correlation between Cylindrospermopsis occurrence and 
$Z_{\text {mix }} / Z_{\text {pho }}$ ratio was found $(\mathrm{r}=0.41, \mathrm{p}=0.009, \mathrm{n}=39)$, while no correlation was found with the other algal groups. According to Soranno (1997), a surface cyanobacterial bloom is very likely to be present if Secchi disk depth is $<1.5 \mathrm{~m}$ and $Z_{\text {mix }} / Z_{\text {pho }}$ is $>2.56$. Throughout the survey, the environmental conditions seemed to support those predictions. This high turbidity of mixed layer and the high light limitation for phytoplankton $\left(Z_{\text {mix }} / Z_{\text {pho }}>1.5\right)$ can discriminate the Rstrategists, especially the $\mathrm{Sn}$ assemblages such as Cylindrospermopsis (Reynolds 1988).

Most $\mathrm{pH}$ values were high $(>8 ; 64 \%$ of reservoirs), corroborating the fact that this cyanobacterium can take up inorganic carbon at high $\mathrm{pH}$ for its development, as demonstrated by Shapiro (1990) for other cyanobacteria. The ambient chemistry context was also characterized by high alkalinity values (mean of $2096 \mu \mathrm{Eq} \mathrm{^{-1 }}$ ) contributing to the maintenance of constant favorable conditions for the development of Cylindrospermopsis. Conductivity values ranged between 197 and $25000 \mu \mathrm{S} \mathrm{cm}^{-1}$, but Cylindrospermopsis was not present at the highest conductivity (values $>10000 \mu \mathrm{S} \mathrm{cm}^{-1}$ ), despite its high tolerance for variations in ionic composition and to high salinity (Padisák 1997). The dissolved nutrient context also seemed to play a role in the Cylindrospermopsis occurrence. The opposition between nutrient levels (especially ammonium and nitrate concentrations) and C. raciborskii abundance was found, corroborating the results reported by Padisák \& Istvánovics (1997). C. raciborskii takes advantage of its ability to assimilate ammonium at low ambient concentrations (Présing et al. 1996). This is consistent with our results because high percentages of Cylindrospermopsis (mean of 53.6\%) were found in Group II-E (Table 5), which was characterized by the lowest ammonium concentrations $\left(<50 \mu \mathrm{g} \mathrm{l}^{-1}\right)$. It is generally accepted that cyanobacteria dominate in conditions of reduced inorganic N/P ratio $(<29$; Smith 1983). However, Reynolds (1998) argued that caution is advised when this resource-ratio is used to predict algal dominance. In our study, the N/P ratio showed high values (mean of 104.7), and the expected direct relationships between the Cylindrospermopsis occurrence and the N/P ratio was not found, corroborating Reynolds' (1998) conclusion.

The nutrient status of phytoplankton is functionally important because it determines the quality of phytoplankton as food for consumers (Sterner et al. 1993). Therefore, nutrient status can explain competitive interactions of phytoplankton during our investigation. According to Guildford et al. (1994), growth limitation by nitrogen would be regarded as severe if $\mathrm{C} / \mathrm{N}$ ratios were greater than 8.3, and strict if values were greater than 14.6. Our values indicated that the studied reser- voirs were not nitrogen deficient, with a mean ratio of 7.8 and a range from 5.7 to 11.7 . Dissolved N concentrations did not confirm this non-deficiency but revealed a nitrogen limitation in $56 \%$ of the reservoirs showing concentrations $<100 \mathrm{\mu g} \mathrm{l}^{-1}$, which would be a limiting level (Sas 1989). However, the occurrence and the dominance in some reservoirs of the atmospheric nitrogen-fixing cyanobacterium such as Cylindrospermopsis without a great proportion of heterocytes confirmed the observations made by Bouvy et al. (1999) and Huszar et al. (2000). Indeed, these authors claimed that Cylindrospermopsis populations were dominant in non-nitrogen-deficient conditions, knowing that this cyanobacterium takes advantage of its ability to assimilate ammonium at low ambient concentrations (Présing et al. 1996).

Relative abundance of cyanobacteria is often claimed to be directly dependent upon the total phosphorus concentrations, but in our reservoirs, this relation was not observed. This has likewise been mentioned in other typical systems (Huszar \& Caraco 1998). For phosphorus, the 2 indicators (C/P and N/P) showed great ranges with high averages (406 and 72, respectively), indicating that most reservoirs were strongly phosphorus deficient according to the Guildford et al. (1994) criteria (phosphorus deficiency if values $>129$ and 22, respectively). According to Sas (1989), the phosphorus deficiency in our reservoirs was confirmed, with the dissolved concentrations $<10 \mu \mathrm{\mu g} \mathrm{l}^{-1}$ in $70 \%$ of reservoirs. With an average of particulate phosphorus

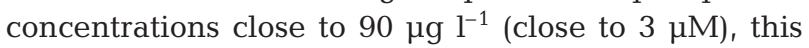
result corroborates the conclusions of Jensen et al. (1994), who pointed out that there was a general dominance of heterocytic cyanobacteria when the phosphorus concentration was less than $8 \mu \mathrm{M}$. Cyanobacterial prokaryotes are capable of intracellular storage of assimilated phosphorus as with many phytoplankton members (Healey 1982). The field data from Lake Balaton (Padisák \& Istvánovics 1997) allow the supposition that Cylindrospermopsis raciborskii can store phosphorus through luxury uptake, explaining the P limitation in the studied reservoirs. This nutrient limitation can also explain the rarity of other phytoplankton species such as Chlorophyceae.

\section{Biological context}

According to the Biological System in the co-inertia analysis, the absence of other phytoplanktonic groups (Euglenophyceae, Chlorophyceae, Bacillariophyceae) when Cylindrospermopsis is dominant is the most significant biological feature in these reservoirs (Fig. 5). It is clear that the presence of this cyanobacterium greatly modifies the plankton structure, and results in 
a substantial decrease in phytoplankton diversity, as described previously by Bouvy et al. (1999). This study reveals that rotifers, cladocerans and copepods had a spatial distribution quite different from that of the cyanobacteria. This probably resulted from their respective feeding behavior because it is well known that each species differed in their selective feeding patterns depending on prey size (Tackx et al. 1989, Pagano et al. 1999). In addition, neurotoxic blooms of Cylindrospermopsis raciborskii were recently reported in some water supply reservoirs (Bouvy et al. 1999, Nascimento et al. 2000) and can affect feeding, growth and reproduction of many zooplankters (Smith \& Gilbert 1995). Nevertheless, preliminary laboratory experiments revealed that if all zooplankton groups can cut filaments of C. raciborskii despite their toxicity, without evidence of ingestion before $48 \mathrm{~h}$, only copepods can ingest the small lengths of the coiled filaments of C. raciborskii (Bouvy \& Molica 1999). Some rotifers such as the genus Brachionus (Fulton \& Paerl 1987) seem resistant to the toxins, but no significant association between rotifers and Cylindrospermopsis proportions was observed from the co-inertia analysis.

Co-inertia analysis revealed that rotifers were more abundant in terms of density than copepods and cladocerans in the most eutrophic, turbid and deoxygenated reservoirs, as reported by Arcifa (1984) in 10 reservoirs in southern Brazil and by Aka et al. (2000) in 49 shallow African reservoirs. These investigations in tropical regions demonstrate that rotifers are more linked to eutrophic conditions than copepods or cladocerans, and corroborate the fact that rotifers require higher food concentrations than crustaceans (DeMott 1989). Bacterial cells, especially those of the largest biovolume (Biov), represent a potential food source for rotifers. Many studies have demonstrated that, despite their small size, bacterial cells could be used successfully for rearing rotifers in experimental conditions (Starkweather et al. 1979, Bouvy et al. 1994). Bacterioplankton did not seem affected by the presence of cyanobacteria in the studied reservoirs because there was no difference in bacterial densities between groups of reservoirs mainly defined by cyanobacterial abundance (Table 5). Many investigators have observed a significant correlation between bacteria and chlorophyll in various ecosystems (Cole et al. 1988, Bouvy et al. 1998b). In the present work, a significant correlation $\left(\mathrm{r}^{2}=0.587, \mathrm{n}=39\right)$ was also observed between these 2 compartments, suggesting that cyanobacterial (e.g. Cylindrospermopsis) products are potentially important substrates for bacterioplankton growth, as demonstrated by Wang \& Priscu (1994).

\section{Factors favoring the development of Cylindrospermopsis}

Clear links exist between the occurrence of Cylindrospermopsis and the environmental context of reservoirs as outlined above. The negative relationship between cyanobacteria abundance and nutrients merits comment because cyanobacteria are commonly encountered in nutrient-rich shallow reservoirs. Other algal groups seemed more dependent on high nutrient levels, which implies that once the nutrient stock is exhausted, and without restocking from deep layers, the development of these algal groups would be limited by nutrients. In contrast, Cylindrospermopsis probably develops rapidly when nutrient concentrations are at their lowest levels. The climate change linked to the 1997 El Niño phenomenon in north-east Brazil has favored the ecological conditions for the development of cyanobacteria in many reservoirs. Volume reduction, water column stability (lack of turbulence) and long water retention time (lack of water renewal) in the reservoirs linked to the drought would have created excellent conditions of temperature and irradiation for the dominance of Cylindrospermopsis sp. This climatic change could also explain the absence of a relationship between the location of the reservoirs in a given hydrological basin and the occurrence of Cylindrospermopsis.

Finally, this survey has provided the first regional study of the occurrence of the genus Cylindrospermopsis at a state scale in Brazil. Co-inertia analysis coupled with a Ward's aggregation defined 2 main groups of reservoirs. The first group, representing $30 \%$ of the studied reservoirs, corresponded to poorly oxygenated, shallower and less eutrophic sites characterized by lower temperature and $\mathrm{pH}$ values, and higher levels of dissolved nutrients associated with Chlorophyceae and Bacillariphyceae. The second group (70\% of reservoirs) corresponded to deeper, warmer and hypertrophic reservoirs characterized by the combination of lower ammonia concentration, higher temperature and $\mathrm{pH}$ values and higher percentages of Cylindrospermopsis. The high degree of association between the Environmental and Biological Systems obtained from the coinertia analysis enabled us to make ecological interpretations based on this classification. It is obvious that the presence of cyanobacteria, especially Cylindrospermopsis sp., induced a decrease in the phytoplankton biodiversity linked to an increase in temperature and $\mathrm{pH}$ values and a decrease in light and nutrient concentrations. No obvious spatial distribution pattern in Pernambouc State could be reported for the 25 reservoirs containing the genus Cylindrospermopsis. 
In the future, more information will be required about the toxicological effects of Cylindrospermopsis on the microbial components and zooplankton communities. Potential pathways for interactions between fish and cyanobacteria have received little attention in Brazil (e.g. Starling \& Rocha 1990), especially in northeastern Brazil. Nevertheless, potential pathways for interaction between fish and cyanobacteria have been used in attempts to control their blooms in eutrophic temperate lakes (e.g. Pinel-Alloul et al. 1998). The role of freshwater fish in the trophic organization of tropical aquatic system affected by Cylindrospermopsis blooms should be analyzed by means of mesocosm experiments employing a holistic approach.

Acknowledgements. The authors are indebted to Dr J. Padisák for helpful comments on an earlier draft of the manuscript. We gratefully acknowledge Monique Simier (IRD center) for advice on ADE-4 data analysis. We are grateful to the 2 reviewers for their criticisms and constructive comments. This work is part of the IRD/UFRPE 'Açudes' Project.

\section{LITERATURE CITED}

Aka M, Pagano M, Saint-Jean L, Arfi R, Bouvy M, Cecchi P, Corbin D, Thomas S (2000) Zooplankton variability in 49 shallow tropical reservoirs of Côte d'Ivoire (West Africa). Int Rev Ges Hydrobiol 85:491-504

Arcifa MD (1984) Zooplankton composition of ten reservoirs in southern Brazil. Hydrobiologia 113:137-145

Azevedo SMFO (1996) Toxic cyanobacteria and the Caruaru tragedy. Proc IV Symp Brazilian Soc Toxicol, p 83

Boon PI, Bunn SE, Green JD, Shiel RJ (1994) Consumption of cyanobacteria by freshwater zooplankton; implications for the success of 'top-down' control of cyanobacterial blooms in Australia. Aust J Mar Freshw Res 45:875-887

Borics G, Grigorszki I, Szabo S, Padisák J (2000) Phytoplankton associations under changing pattern of bottom-up vs. top-down control in a small hypertrophic fishpond in East Hungary. Hydrobiologia 424:79—90

Bouvy M, Molica RJR (1999) Avaliação da ingestão de Cylindrospermopsis pelo zooplâncton: testes em laboratório. Anais do VII Congresso Brasileiro Ficologia, 22-26 September 1999, Porto de Galinhas, Brazil

Bouvy M, Arfi R, Guiral D, Pagano M, Saint-Jean L (1994) Role of bacteria as food for zooplankton in a eutrophic tropical pond (Ivory Coast). Neth J Aquat Ecol 28:167-174

Bouvy M, Barros Franca L, Carmouze JP (1998a) Compartimento microbiano no meio pelágico de sete açudes do estado de Pernambuco (Brasil). Acta Limnol Brasil 10: 93-101

Bouvy M, Arfi R, Cecchi P, Corbin D, Pagano M, Saint-Jean L, Thomas S (1998b) Trophic coupling between bacterial and phytoplanktonic compartments in shallow tropical reservoirs (Côte d'Ivoire, West Africa). Aquat Microb Ecol 15:25-37

Bouvy M, Molica RJR, De Oliveira S, Marinho M, Beker B. (1999) Dynamics of a toxic cyanobacterial bloom (Cylindrospermopsis raciborskii) in a shallow reservoir in the semi-arid region of Northeast Brazil. Aquat Microb Ecol 20:285-297

Carlson RE (1977) A trophic state index for lakes. Limnol Oceanogr 22:361-69
Carmichael WW (1994) The toxins of cyanobacteria. Sci Am 270:78-86

Codd GA (1995) Cyanobacterial toxins: occurrence, properties and biological significance. Wat Sci Tech 32:149-56

Cole JJ, Findlay S, Pace ML (1988) Bacterial production in fresh and saltwater ecosystems: a cross-system overview. Mar Ecol Prog Ser 43:1-10

Couté A, Leitao M, Martin C (1997) Première observation du genre Cylindrospermopsis (Cyanophyceae, Nostocales) en France. Cryptogamie Algol 18:57-70

DeMott WR (1989) The role of competition in zooplankton succession. In: Sommer U (ed) Plankton ecology. Succession in plankton communities. Springer Verlag. New York, p 195-252

Dolédec S, Chessel D (1994) Co-inertia analysis: an alternative method for studying species-environment relationships. Freshw Biol 31:277-94

Fabbro LD, Duivenvoorden LJ (1996) Profile of a bloom of the cyanobacterium Cylindrospermopsis raciborskii (Wolosszynska) Seenaya and Subba Raju in the Fitzroy River in tropical central Queensland. Mar Freshw Res 47:685-694

Forsberg C, Ryding SO (1980) Eutrophication parameters and trophic state indices in 30 Swedish waste-receiving lakes. Arch Hydrobiol 89:189-207

Fulton RS, Paerl HW (1988) Effects of the blue-green algae Microcystis aeruginosa on zooplankton competitive relations. Oecologia 76:383-389

Gran G (1952) Determination of the equivalent point in potentiometric titrations, Part II. Analyst 77:661-671

Guildford SJ, Hendzel LL, Kling HJ, Fee EJ, Robinson GGC, Hecky RE, Kasian SEM (1994) Effects of lake size on phytoplankton nutrient status. Can J Fish Aquat Sci 51:2769-83

Healey FP (1982) Phosphate. In: Carr NG, Whitton BA (eds) The biology of cyanobacteria. Blackwell Scientific, Oxford, p 105-124

Huszar VLM, Caraco (1998) The relationship between phytoplankton composition and physical-chemical variables: a comparison of taxonomic and morphological-functional approaches in six temperate lakes. Freshw Biol 40:1-18

Huszar VLM, Silva LHS, Domingos P, Marinho M, Melo S (1998) Phytoplankton species composition is more sensitive than OECD criteria to the trophic status of three Brazilian tropical lakes. Hydrobiologia 369/370:59-71

Huszar VLM, Silva LHS, Marinho M, Domingos P, Sant'Anna CL (2000) Cyanoprokaryote assemblages in eight productive tropical Brazilian waters. Hydrobiologia 424:67-77

Jensen PE, Jeppesen K, Olrik K, Kristensen P (1994) Impact of nutrients and physical factors on the shift from cyanobacterial to chlorophyte dominance in shallow Danish lakes. Can J Fish Aquat Sci 51:1692-1699

Jochimsen EM, Carmichael WW, An J, Cardo DM, Cookson ST, Holmes CEM, Antunes BC, Melo Filho DA, Lyra TM, Barreto VST, Azevedo SMFO, Jarvis WR (1998) Liver failure and death after exposure to microcystins at a hemodialysis center in Brazil. New Engl J Med 338:873-878

Kerr RA (1998) Models win big in forecasting in El Niño. Science 280:522-523

Komárková-Legnerová J, Tavera R (1996) Cyanoprokaryota (Cyanobacteria) in the phytoplankton of Lake Catemaco (Veracruz, Mexico). Algol Stud 83:403-422

Komárková J, Laudares-Silva R, Senna PAC (1999) Extreme morphology of Cylindrospermopsis raciborskii (Nostocales, Cyanobacteria) in the lagoa Do Peri, a freshwater coastal lagoon, Santa Catarina, Brazil. Algol Stud 94:207-22

Koroleff F (1976) Determination of nutrients. In: Grasshoff K (ed) Methods of seawater analysis. Verlag Chemie, Weinheim, p 117-182 
Krambeck C, Krambeck KHJ, Overbeck J (1981) Microcomputer assisted biomass determination of plankton bacteria on scanning electron micrographs. Appl Environ Microbiol 42:142-149

Lagos N, Onodera H, Zagatto PA, Andrinolo D, Azevedo SMFQ, Oshima Y (1999) The first evidence of paralytic shellfish toxins in the freshwater cyanobacterium Cylindrospermopsis raciborskii, isolated from Brazil. Toxicon 37:1359-1373

Margalef R (1983) Limnologia. Ediciones Omega, Barcelona

Nascimento SM, Molica RJR, Bouvy M, Ferreira A, Silva LHS, Huszar V, Azevedo S (2000) Toxic cyanobacterial blooms in the Tapacurá reservoir, Northeast Brazil. 9th Int Conf on Harmful Algal bloom, Tasmania, Feb 2000, p 186

Nixdorf B, Deneke R (1997) Why 'very shallow' lakes are more successful opposing reduced nutrient loads. Hydrobiologia 342:269-284

OECD (Organization for Economical Cooperation and Development) (1982) Eutrophication of waters. Monitoring, assessment and control. OECD, Paris

Padisák J (1997) Cylindrospermopsis raciborskii (Woloszynska) Seenayya et Subba Raju, an expanding, highly adaptive cyanobacterium: worldwide distribution and review of its ecology. Arch Hydrobiol Suppl 107:563-593

Padisák J (1998) Sudden and gradual responses of phytoplankton to global climate change: case studies from two large, shallow lakes (Balaton, Hungary; Neusiedlersee, Austria/ Hungary) In: George DG, Jones JG, Puncochar P, Reynolds CS, Sutcliffe DW (eds) Management of lakes and reservoirs during global change. Kluwer Academic Publishers, Dordrecht, p 111-125

Padisák J, Istvánovics V (1997) Differential response of bluegreen algal groups to phosphorus load reduction in a large shallow lake Balaton, Hungary. Verh Int Verein Limnol 26: $574-580$

Padisák J, Reynolds CS (1998) Selection of phytoplankton associations in lake Balaton, Hungary, in response to eutrophication and restoration measures, with special reference to the cyanoprokaryotes. Hydrobiologia 384:41-53

Paerl HW (1988) Nuisance phytoplanktonic blooms in coastal, estuarine and inland waters. Limnol Oceanogr 33:823-847

Pagano M, Saint-Jean L, Arfi R, Bouvy M, Guiral D (1999) Zooplankton food limitation and grazing impact in a eutrophic brackish-water tropical pond (Côte D'Ivoire, West Africa). Hydrobiologia 390:83-98

Pereira DF, Bouvy M, Marinho M, Moura A (1999) Microfitoplâncton e condições limnológicas em reservatórios de cinco bacias hidrográficas do Estado de Pernambuco. Anais do VII Congresso Brasileiro Ficologia, 22-26 September 1999, Porto de Galinhas, Brazil

Pinel-Alloul B, Mazumder A, Lacroix G, Lazzaro X (1998) Lake trophic food webs: structure, function, interactions and spatio-temporal variations. Rev Sci Eau 11:163-197

Porter KG, Feig YS (1980) The use of DAPI for identifying and counting aquatic microflora. Limnol Oceanogr 25:943-948

Présing M, Herodek S, Vörös L, Kóbor I (1996) Nitrogen fixation, ammonium and nitrate uptake during a bloom of Cylindrospermopsis raciborskii in Lake Balaton. Arch Hydrobiol 136:553-562

Reynolds CS (1988) Functional morphology and the adaptive strategies of freshwater phytoplankton. In: Sandgren CD (ed) Growth and reproductive strategies of freshwater phytoplankton. Cambridge University Press, New York, p 388-433

Reynolds CS (1994) The long, the short and the stalled: on the attributes of phytoplankton selected by physical mixing in lakes and rivers. Hydrobiologia 289:9-23

Reynolds CS (1998) What factors influence the species composition of phytoplankton in lakes of different trophic status? Hydrobiologia 369/370:11-26

Saker ML, Neilan BA, Griffiths DJ (1999) Two morphological forms of Cylindrospermopsis raciborskii (Cyanobacteria) isolated from Solomon Dam, Palm Island, Queensland. J Phycol 35:599-606

Sas H (1989) Lake restoration by reduction of nutrient loading: expectations, experiences, extrapolations. Academia Verlag Richarz, St. Augustin

Shapiro J (1990) Current beliefs regarding dominance by blue green-algae: the case for the importance of $\mathrm{CO}_{2}$ and pH. Verh Int Ver Theor Angew Limnol 24:38-54

Smith VH (1983) Low nitrogen to phosphorus ratios favor dominance by blue green-algae in lake phytoplankton. Science 221:669-670

Smith AD, Gilbert JJ (1995) Relative susceptibilities of rotifers and cladocerans to Microcystis aeruginosa. Arch Hydrobiol 132:309-336

Sommer U, Gliwicz ZM, Lampert W, Duncan A (1986) The Plankton Ecology Group model of seasonal succession of planktonic events in fresh waters. Arch Hydrobiol 106: 433-472

Soranno PA (1997) Factors affecting the timing of surface scums and epilimnetic blooms of blue-green algae in a eutrophic lake. Can J Fish Aquat Sci 54:1965-1975

Starkweather PL, Gilbert JJ, Frost TM (1979) Bacterial feeding by the rotifer Brachionus calyciflorus: clearance and ingestion rates and population dynamics. Oecologia 44:26-30

Starling FLRM, Rocha AJA (1990) Experimental study of the impacts of planktivorous fishes on plankton community and eutrophication of a tropical Brazilian reservoir. Hydrobiologia 200/201:581-591

Sterner RW, Hagemeier DD, Smith WL, Smith RF (1993) Phytoplankton nutrient limitation and food quality for Daphnia. Limnol Oceanogr 38:857-871

Strickland JDH, Parsons TR (1972) A practical handbook of seawater analysis. Bull Fish Res Board Can 167

Tackx MLM, Bakker C, Francke JW, Vink TM (1989) Size and phytoplankton selection by Oosterschelde zooplankton. Neth J Sea Res 23:35-43

Talling J (1971) The underwater light climate as a controlling factor in the production ecology of freshwater phytoplankton. Mitt Int Ver Theor Angew Limnol 19:214-243

Talling J, Lemoalle J (1998) Ecological dynamics of tropical inland waters. Cambridge University Press, Cambridge

Thioulouse J, Chessel D, Dolédec S, Olivier JL (1997) ADE-4: a multivariate analysis and graphical display software. StatComp 7:75-83

Tóth GL, Padisák J (1986) Meteorological factors affecting the bloom of Anabaenopsis raciborskii Wolosz. (Cyanophyta: Hormogonales) in the shallow lake Balaton, Hungary. J Plankton Res 8:353-363

Tundisi JG, Matsumura-Tundisi T, Calijuri MC (1993) Limnology and management of reservoirs in Brazil. In: Straskraba M, Tundisi JG, Duncan A (eds) Comparative limnology and water quality management. Kluwer Academic Publishers, Dordrecht, p 25-55

Wang L, Priscu JC (1994) Stimulation of aquatic bacterial activity by cyanobacteria. Hydrobiologia 277:145-158

Yentsch CS, Menzel DW (1963) A method for the determination of phytoplankton chlorophyll and pheophytin by fluorescence. Deep-Sea Res 10:221-231

Submitted: July 10, 2000; Accepted: October 25, 2000

Proofs received from author(s): November 22, 2000 